\title{
Histological and Quantitative Study of the Effect of Eruca Sativa Seed Oil on The Testis of Albino Rat
}

\author{
Mona A. R. Salem and Nehal A. Moustafa* \\ From Histology Dep., Faculty of Medicine And Zoology Dep., * \\ Faculty of Science, Al-Azhar University (Girls)
}

\begin{abstract}
Eruca Sativa (E.S) or Gargir seed oil is widely used in folk medicine. This study was conducted to investigate its possible effect on male rat fertility. Histological changes of the testis, level of testosterone hormone and sperm count were determined.

The results revealed that administration of low dose of E.S. seed oil caused dilatation of the seminiferous tubules, proliferation of spermatogenic cells and increase of its mitotic activity. Increased number of sperms and epididymis weight, elevated level of testosterone hormone and hyperplasia of interstitial Leydig cells have also been noticed. DNA analysis revealed an increase of the percentage of haploid and decrease of diploid and tetraploid cells. Administration of E.S. seed oil at higher dose showed. decreased diameter of the seminiferous tubules, reduced spermatogenic activity and number of sperms . Also testosterone hormone level decreased and the interstitial cells appeared few. DNA analysis showed a reduction of the percentage of the haploid and increase of the percentage of diploid and tetraploid cells.
\end{abstract}

\section{Introduction}

Eruca Sativa (E.S) is known in Egypt as Gargir. The seeds have long been used in folk medicine as a lactagogue, aphrodisiac, diuretic, antis corbutic, antimicrobial, to disintegrate renal calculi and induce vomiting ( Greve, 1959 and Boulos, 1983).

Flanders and Abdel-Karim (1985) proved that E.S seed oil contain $93.8 \%$ fatty acids: $6.7 \%$ saturated acids, 58.5 \%erucic acid, $4.5 \%$ oleic acid, $28.5 \%$ linoleic acid and 1-2\% linolenic acid.

In 1990, Thabit found that Eruca Sativa mill has a diuretic effect on the dog. Also, the seeds contain cancer chemoprotective substances (Gerhauser et al., 1997). According to EL-Gendy (2000), Eruca Sativa oil increased RBC's count and its haemoglobin content. Analysis of serum elements revealed normal concentrations of sodium, $\mathrm{K}$ and $\mathrm{Mg}$ following E.S oil treatment whereas iron concentrations increased as the dose increased.

This study was performed to investigate the expected effects of the widely used E.S seed oil on male fertility and on the histological structure of the testis and to detect any side effects if present.

\section{Materials And Methods}

Thirty adult male albino rats, weighing 150-170 $\mathrm{g}$ were used in this study. They were assigned into three groups of 10 animals each . The 1st gro up served as control. The 2nd and 3rd groups were given two doses of E.S. seed oil (o.25 and $0.5 \mathrm{ml} / \mathrm{kg}$ ) respec tively (Thabit, 1990) three times/ week (day after day) for 6 weeks. The oil

Refree : Prof . Dr. Hassan S. EL- Dawi 
used was obtained by crushing of E.S seeds and was given to the rats by forced feeding using a gastric tube.

At the end of the experimental period, blood samples were collected from the orbital sinus after 12 hour fasting under light ether anaethesia and put into clean tubes to clot. Serum was separated by centrifugation for the detection of serum testosterone level by radioimmunoassay using $\mathrm{I}^{125}$ kit (Diagnostic Products Corporation, U.S.A.). Then the animals were sacrificed and both testes and epididymes were removed immediately and their weights were recorded. Each epididymis was placed in 1-ml normal saline, and cut into small pieces to release the sperms. The specimen was diluted 1 in 100 with $5 \%$ sod. bicarbonate in 1-\% formalin solution and mixed well. The sperms were counted using the haemocytometer counting slide.

The testes were fixed in Bouin's solution, processed, sectioned and sta ined with routine $\mathrm{H}$ \& $\mathrm{E}$ for general histological study according to Drury and Wallington (1980). Image analyzer determined the diameter of the semin eferous tubules. At least 10 tubules in each section were measured.

Feulgen stain was performed for the demonstration of DNA content of spermatogenic cells using DNA Kit. (Bacus, 1988) which was spectropho tometrically analyzed and quantitated using CAS 200. Image analyzer system (Elmhurst, IL, USA) and quantitative ploidy analysis software program. At least 5 tubules were assessed; 150-200 cells were analyzed in each specimen. The cells were classified as haploid, diploid and tetraploid on the basis of the measuring DNA content (Takahiro et al., 1997).

\section{Statistical analysis:}

Data were expressed as mean \pm S.E. and unpaired t-test (Student t-test) was used to compare the difference between each two groups (Willams, 1985). A level of $p<0.05$ was accepted as statistically significant.

\section{Results}

\section{1- General structure: \\ Group I:}

Control testis was enclosed within a thick fibrous capsule, the tunica albuginea (TA), tunica vasculosa was loose C.T. related to the inner aspect of T.A., (Fig.1). The semini ferous tubules appeared rounded or oval, bounded by tunica propria contai ning fibroblasts and myoid cells (Figs. 2\&3). Spermatogenic cells lined the tubules in various stages of maturation and Sertoli cells. Spermat ogenic cells included spermatogonia type A and type B, the largest primary spermatocytes, the smaller rarely seen secondary spermatocytes and sperm atids. Mitotic figures were observed in the primary spermatocytes (Fig. 3). Sperms were attached to the apices of Sertoli cells, and many sperms were present in the lumena of the seminif erous tubules (Figs. 1\&2). The inter stitial cells were present in-groups in the interstitial tissue between the seminuferous tubules (Fig. 2).

\section{Group II:}

In this group, the animals received E.S. seed oil low dose. The seminiferous tubules appeared dilated and most of their lumina were filled with the increasing number of sperms (Fig. 4). Hyperplasia of spermatogenic cells was observed in most of the tubules. The nuclei of the cells appeared lightly stained and their cytoplasm was 
vacuolated (Fig. 5). The primary spermatocytes were arranged in many layers and their nuclei showed increased mitotic figures. The interstitial cells showed also hyperplasia and their nuclei were also lightly stained and their cytoplasm was vacuolated. (Fig. $6)$.

\section{Group III:}

E.S. seeds oil high dose resulted in shrinkage of most the seminiferous tubules and their lumina were empty. Few tubules appeared normal with few sperms in their lumina (Fig. 7). The spermatogenic cells appeared few, scattered and separated from the basal lamina (Fig. 8). Spermatogonia were few, appeared as only one row, their nuclei were deeply stained. The primary spermatocytes were also few, most of the mitotic figures observed in the primary spermatocytes were in the prophase stage (Fig. 9). The interstitial cells were also few, and most of their nuclei were deeply stained (Fig. 8).

\section{2 - Diameter of seminiferous tubules:}

The mean diameter of the seminiferous tubules of control group was (133394.9 \pm 21463.69$)$ Group II showed highly significant increase in the mean cross section diameter of the seminiferous tubules (245662.4 \pm 122314.7) when compared to the control group. In-group III, the high dose of E.S. seeds oil caused a signifi cant decrease of the mean seminiferous tubule diameter $(87706.57 \pm 28240.28)$ when compared to the control group (table 1 histogram 1).

\section{3- D.N.A. analysis:}

Group I:

In control group, DNA analysis showed that the percentage of haploid cells (spermatozoa and spermatids) was $20.1 \%$, diploid cells (Sertoli and G1/ G0 spermatogonia cells) was $46.23 \%$, tetraploid cells (primary spermatoc ytes and G2/M spermatogonia) was $15.58 \%$ and S-phase cells was $15.58 \%$ (table 2 histogram 2).

\section{Group II:}

The percentage of haploid cells was $39.97 \%$ diploid cells $21.17 \%$, tetraploid cells $10.47 \%$ and S-phase cells was $37.39 \%$ (table 2 histogram 3 ).

\section{Group III:}

Haploid cells percentage decreased to be $9.31 \%$; diploid cells percetage increased to be $57.47 \%$, tetraploid cells percentage was higher than other groups $24.03 \%$ and S-phase cells percentage decreased to be $9.2 \%$ (table 2 histogram 4).

\section{4- Sperm count:}

In the present study, oral administration of E.S. seed oil resulted in elevation of sperm count in the epididymis of group II. This increase was significant $(\mathrm{P}<0.05)$. However, this value decreased significantly in group III receiving the higher dose $(\mathrm{P}<0.01)$ (table 3 histogram 5).

\section{5- Testosterone hormone level:}

As shown in table (4) and histogram (6), the level of testosterone hormone in the serum increased after ingestion with low dose of E.S. seed oil in group II and decreased in group III. Though the difference noted was of no significance.

\section{6- Testis and epididymis weights:}

In the present study, E.S. seed oil increased the testis weight in all groups when compared to control, however the difference was only trend. On the other hand, the epididymis weight of the animals in-group II was significantly higher than control, but the higher dose showed non-significant increase $(\mathrm{P}<0.05)($ table 5 histogram 7$)$. 


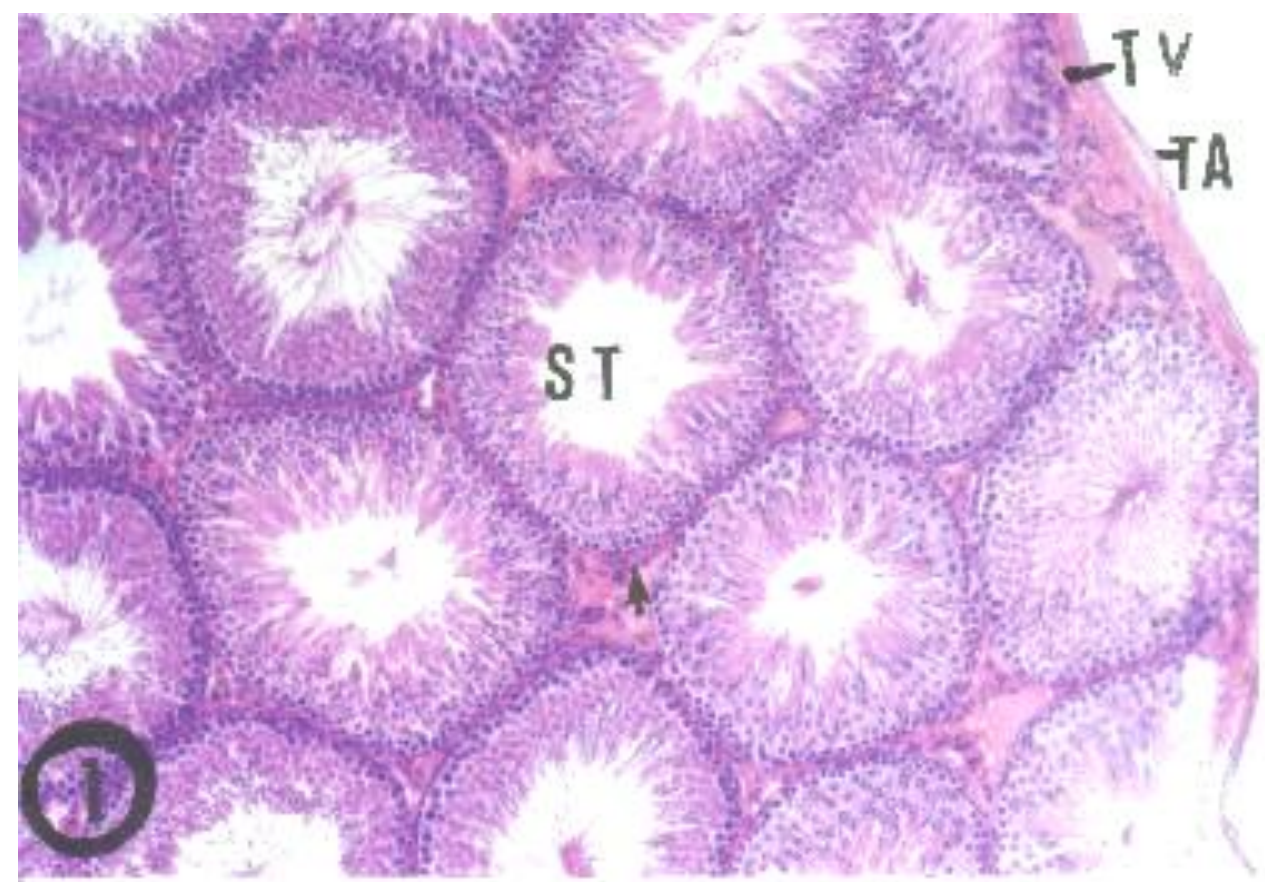

Fig. (1): Photomicrograph of a section in rat testis of control group showing tunica albuginea (TA), tunica vasculosa (TV) and cross sections of seminiferous tubules (ST) surrounded by tunica propria $(\uparrow)$. Notice the sperms in the lumen of seminiferous tubules.

(H \& E x 100).

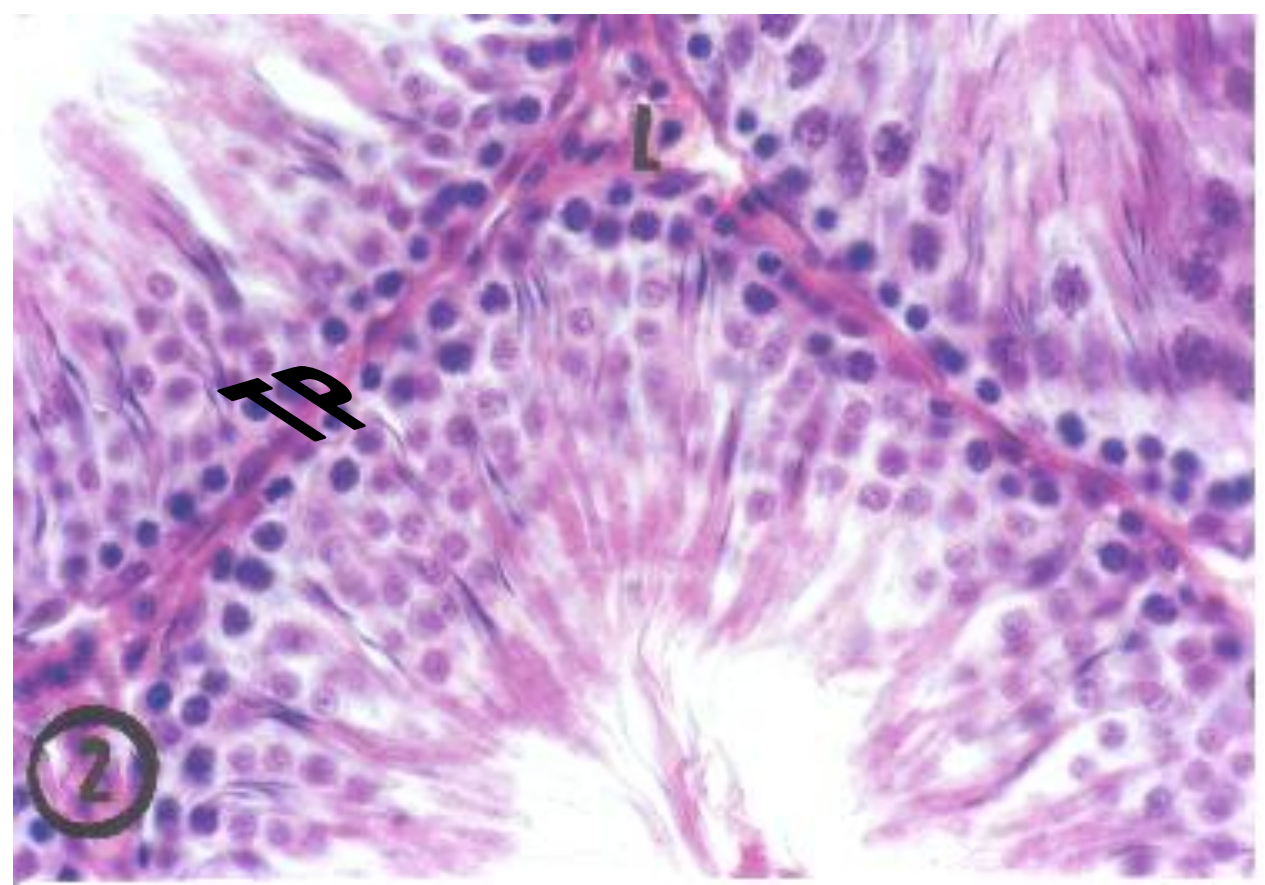

Fig. (2): Higher magnification of part of the previous section showing Seminiferous tubules lined by spermatogenic cells. Notice the clumps of interstitial cells of Leydig (L).Notice also the tunica propria (T.P).

(H \& E x 400). 


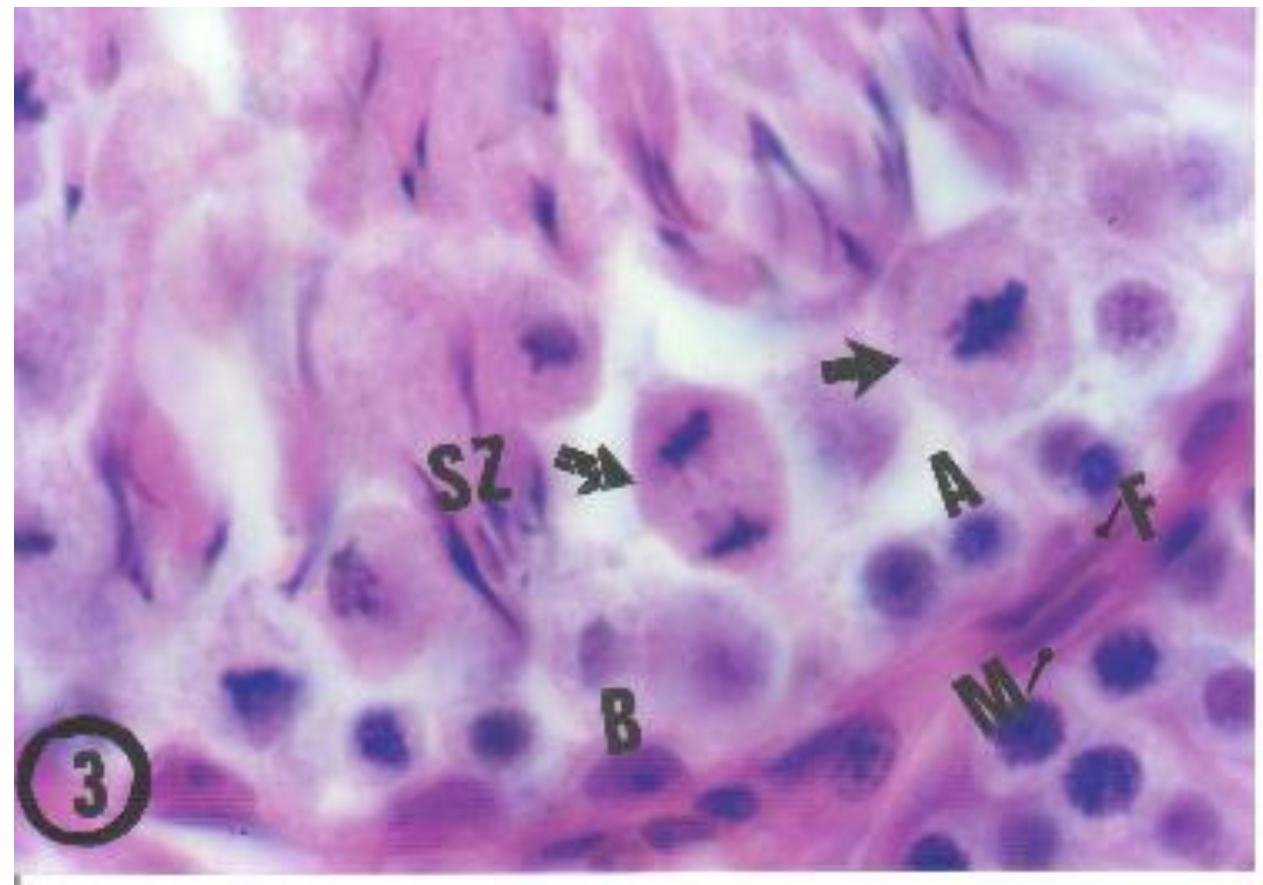

Fig. (3): Photomicrograph of a section of control group showing spermatogonia of various types $\mathrm{A}$ and $\mathrm{B}$, many stages of primary spermatocytes $(\boldsymbol{\uparrow})$. Spermatozoa (SZ) are embeded in Sertoli cells . Notice the fibroblast(F) and the myoid cell $(\mathrm{M})$.

(H\&E x 1000).

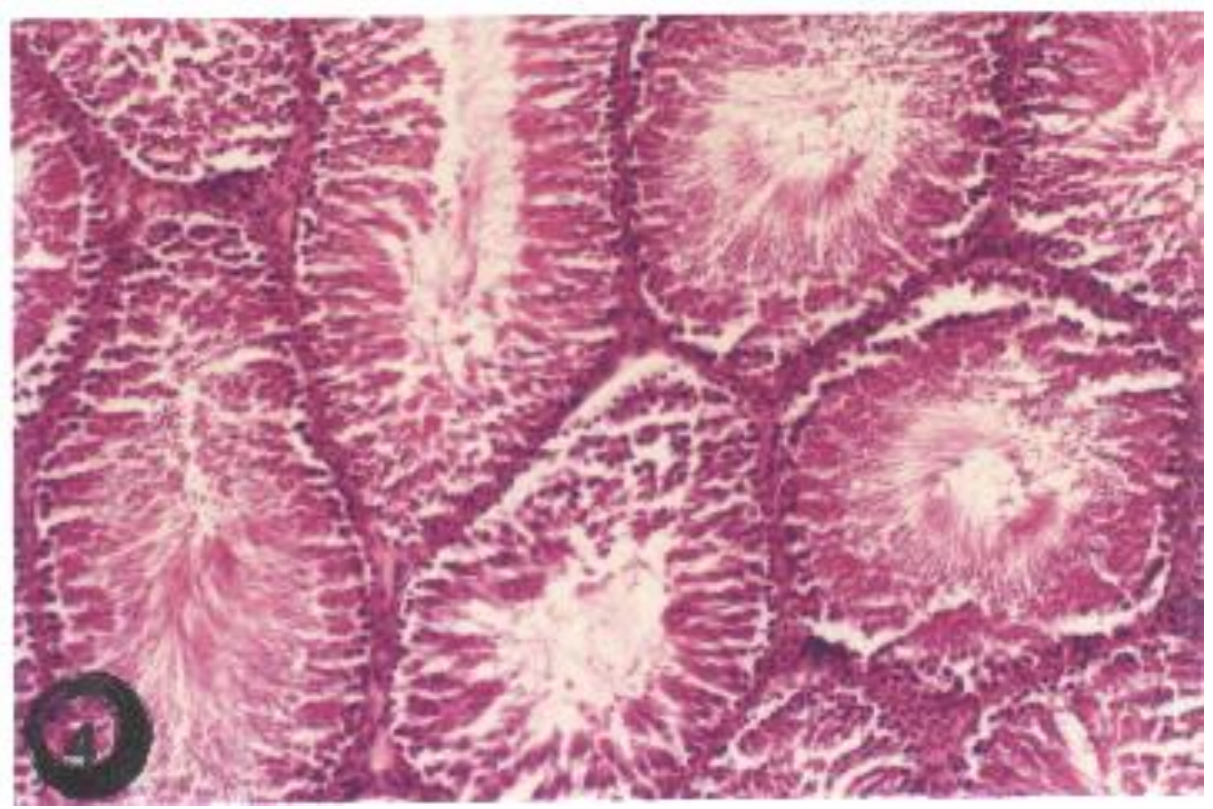

Fig. (4): Photomicrograph of a section of group II showing enlarged seminiferous tubules, their lumina are filled with sperms.

(H\&E x 100). 
Mona A. R. Salem \& Nehal A. Moustafa

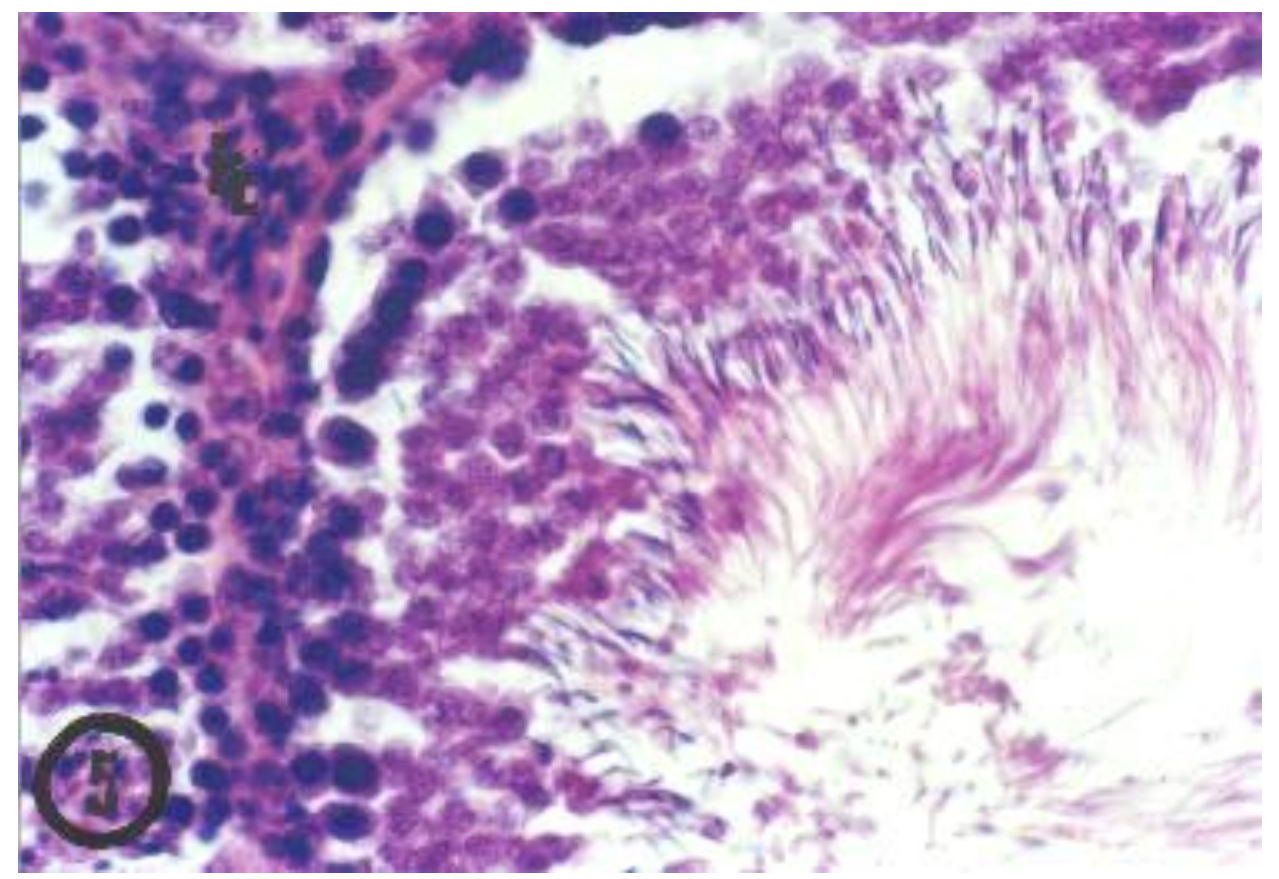

Fig. (5): Photomicrograph of a section of group II showing hyperplasia and overcrowding of spermatogenic cells and hyperplasia of Leydig cell(L).

(H \& E x 400).

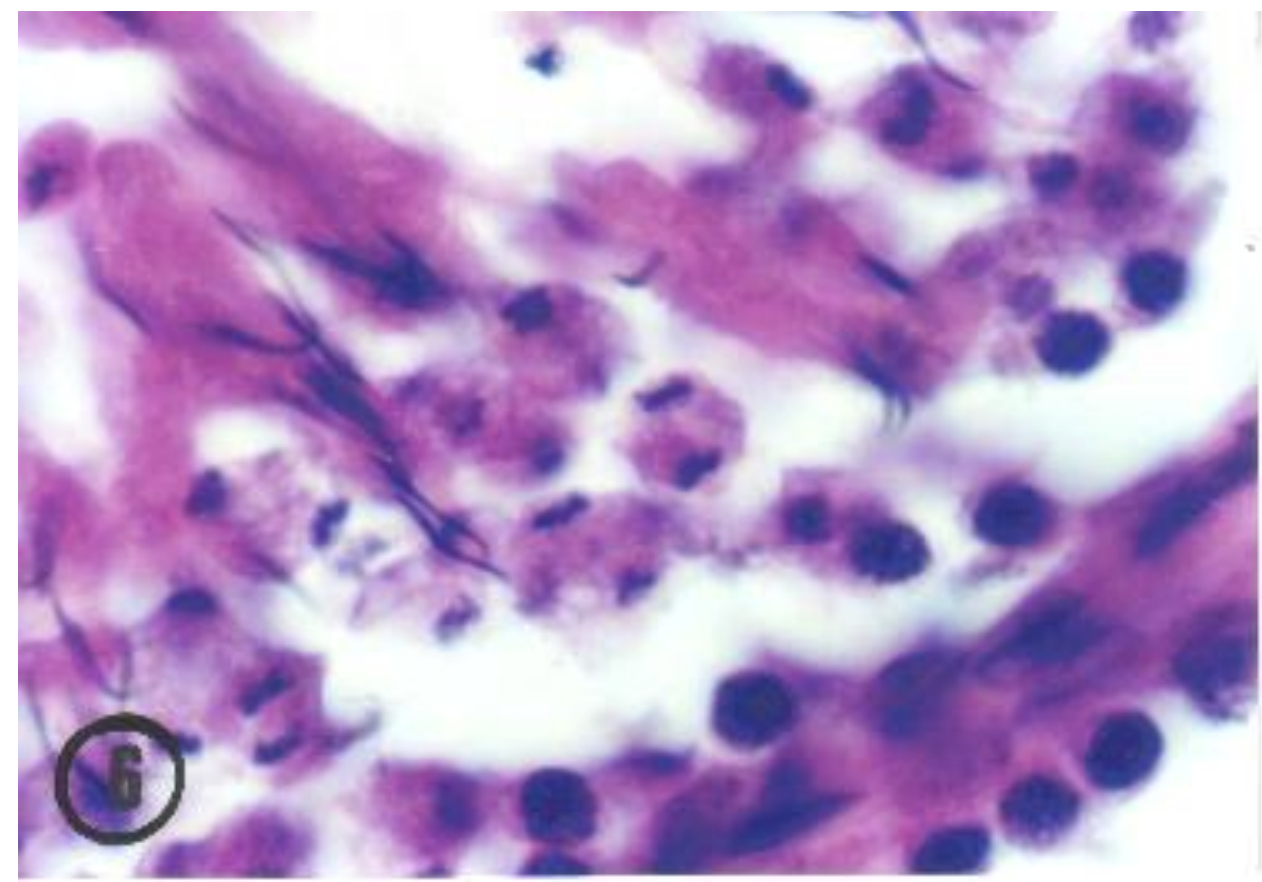

Fig. (6): Photomicrograph of a section of group II showing increased mitotic figures of primary spermatocytes.

(H \& E x 1000). 


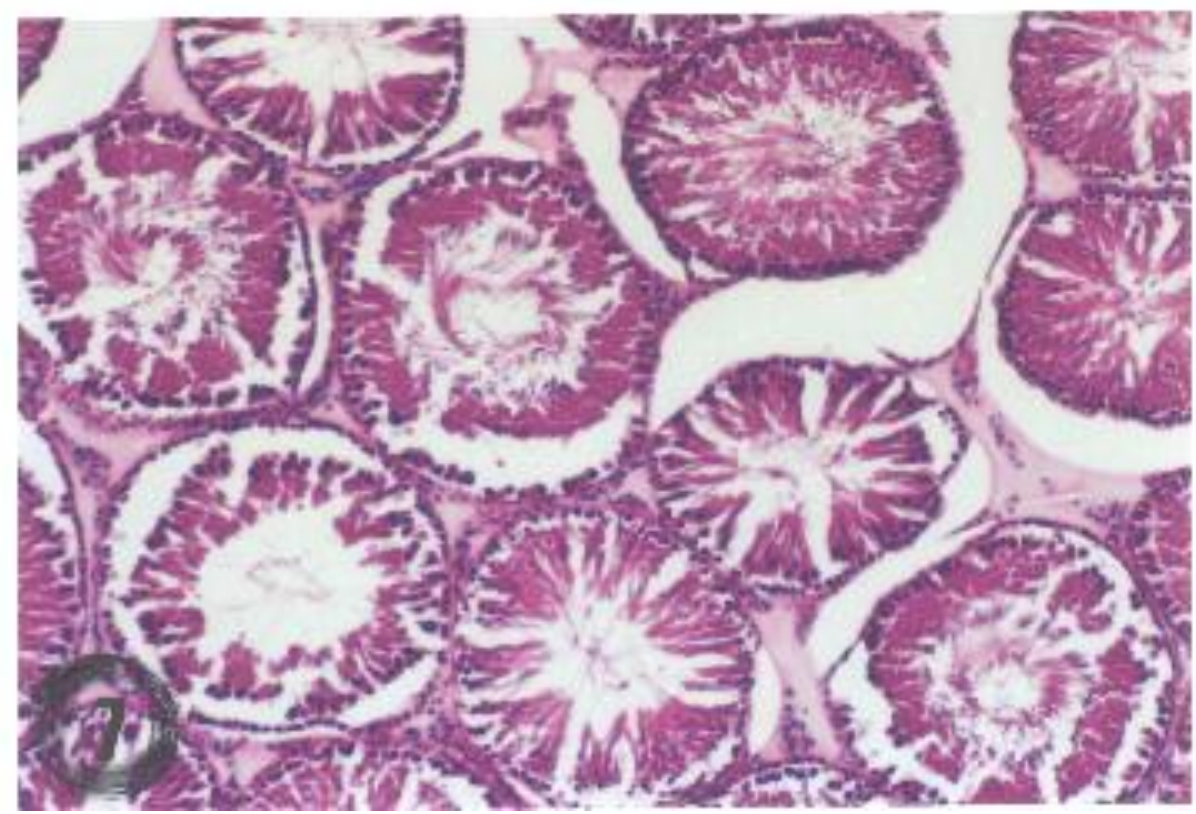

Fig. (7): Photomicrograph of a section of group III showing shrunk distorted seminiferous tubules contain detatched spermatogenic cells and few sperms. (H\&E x 100).

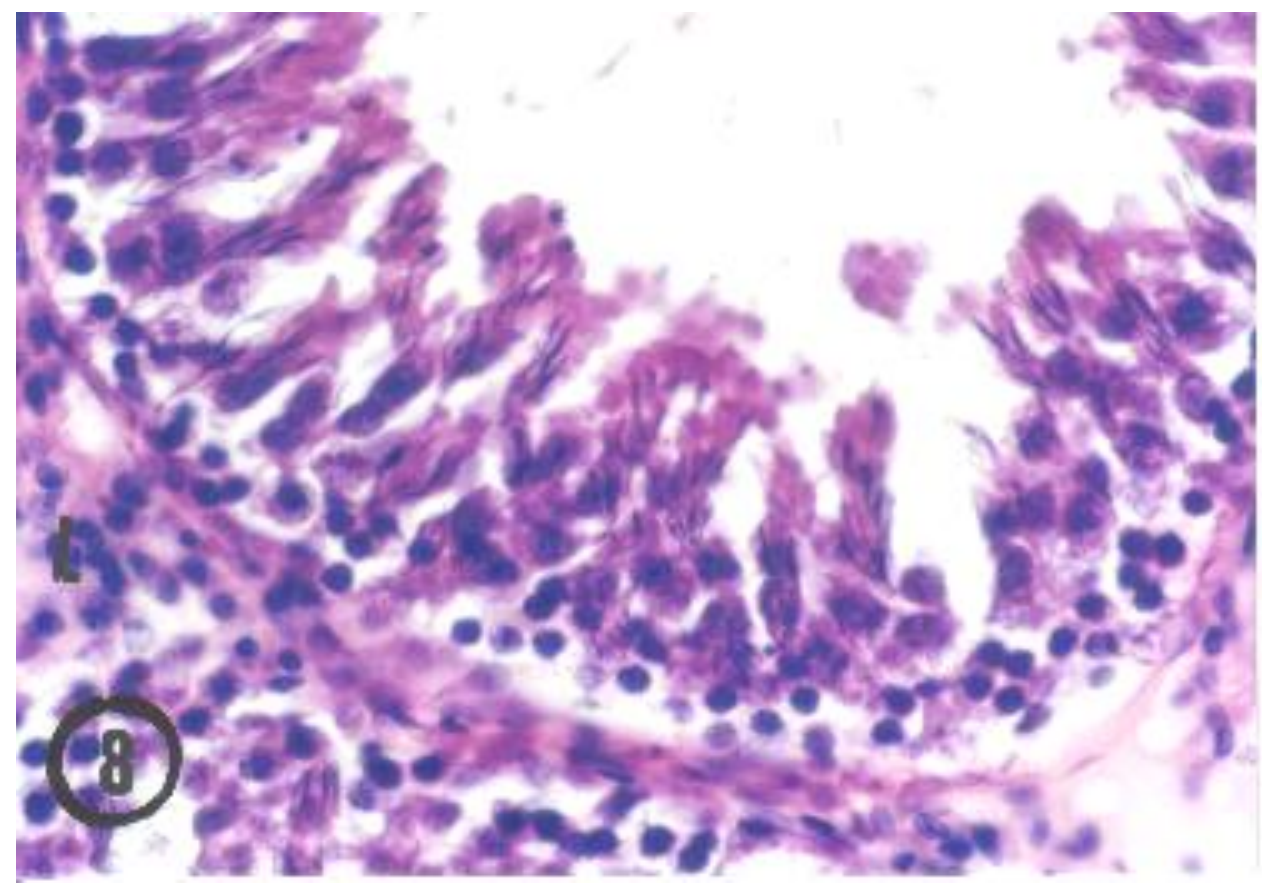

Fig. (8): Photomicrograph of a section of group III showing one row of deeply stained spermatogonia. Notice also the few deeply stained Leydig cells (L).

(H \& E x 400). 


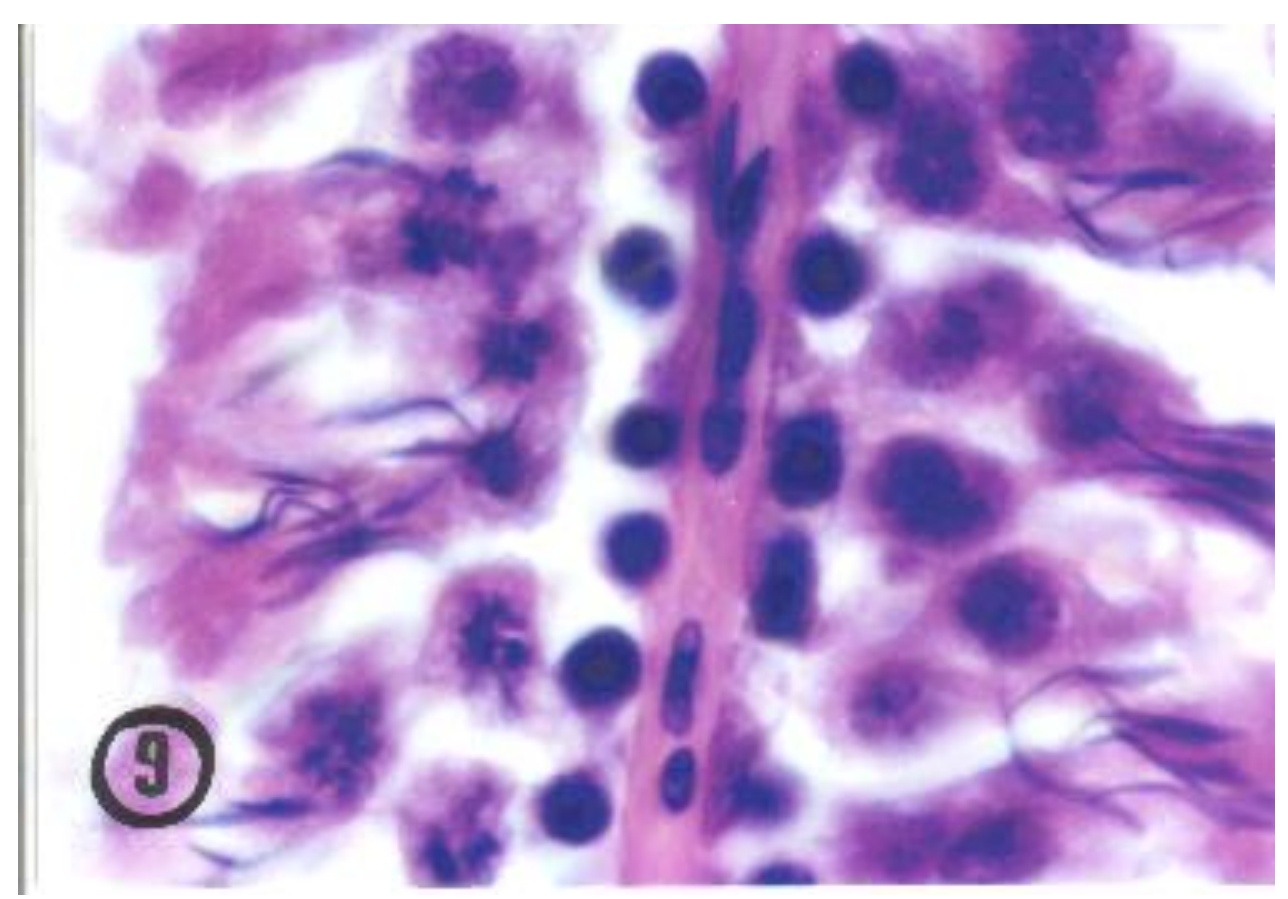

Fig. (9):Photomicrograph of a section of group III showing few primary spermatocytes, notice that most of the mitotic figure are in prpophase stage.

(H \& E x 1000).

Table (1): Effect of E.S. seed oil on the diameter of seminiferous tubules.

\begin{tabular}{|c|c|c|c|}
\hline & Group I & Group II & Group III \\
\hline Max & 161962.2 & 521753.4 & 158142 \\
\hline Min & 101491.7 & 152895.6 & 46322.02 \\
\hline Mean & 133394.9 & 245662.4 & 87706.75 \\
\hline \pm SD & 21463.69 & 122314.7 & 28240.28 \\
\hline P-value & & P $<0.05$ & P $<0.001$ \\
\hline Significance & & HS & HS \\
\hline
\end{tabular}

Histogram (1): Effect of E.S. seed oil on the diameter of seminiferous tubules

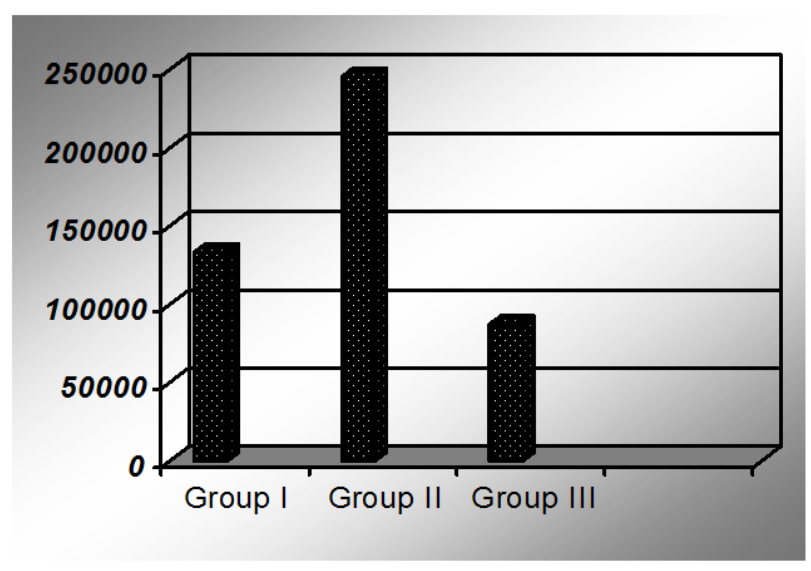




\section{D.N.A analysis}

Table (2): Percentage of total cells counted

\begin{tabular}{|c|c|c|c|}
\hline & Group I & Group II & Group III \\
\hline Haploid cells & $20.1 \%$ & $39.97 \%$ & $9.31 \%$ \\
\hline Diploid cells & $46.23 \%$ & $21.17 \%$ & $57.447 \%$ \\
\hline Teraploid cells & $15.58 \%$ & $10.47 \%$ & $24.03 \%$ \\
\hline S-phase cells & $15.58 \%$ & $37.39 \%$ & $37.39 \%$ \\
\hline
\end{tabular}

Histogram (2): DNA histogram of group I showing diploid peak.

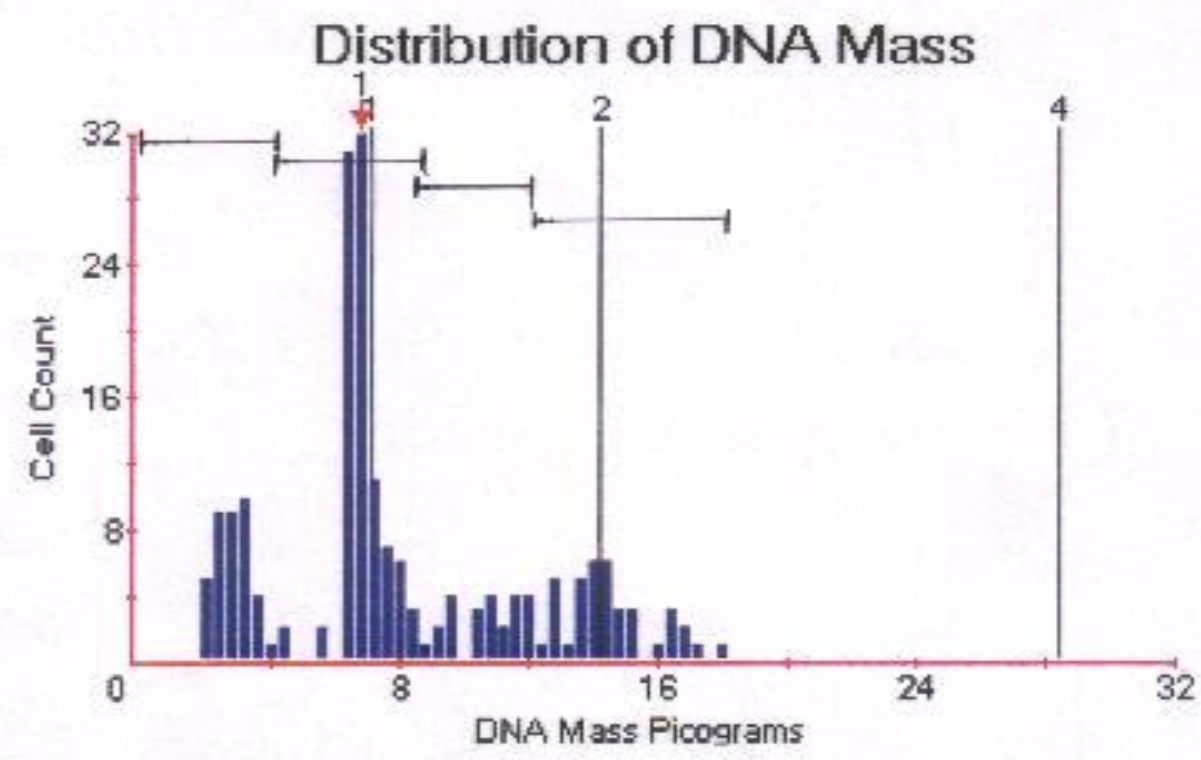

Cell Classes

Displayed : 123456

First Peak

Mass: 7.0 Pg.

DNA Index :0.97

Area: $32.0 \mu^{2}$

Cells : 32

Second Peak

Mass: 0.0 Pg.

DNA index : 0.00

Area : $0.0 \mu^{2}$

Cells : 0

Field Count : 22

Total Cell Count :199

Cells Displayed : 199

Cells Off Scale : 0

Histogram (3): DNA histogram of group II showing haploid and s phase Cells peaks.

\section{Distribution of DNA Mass}

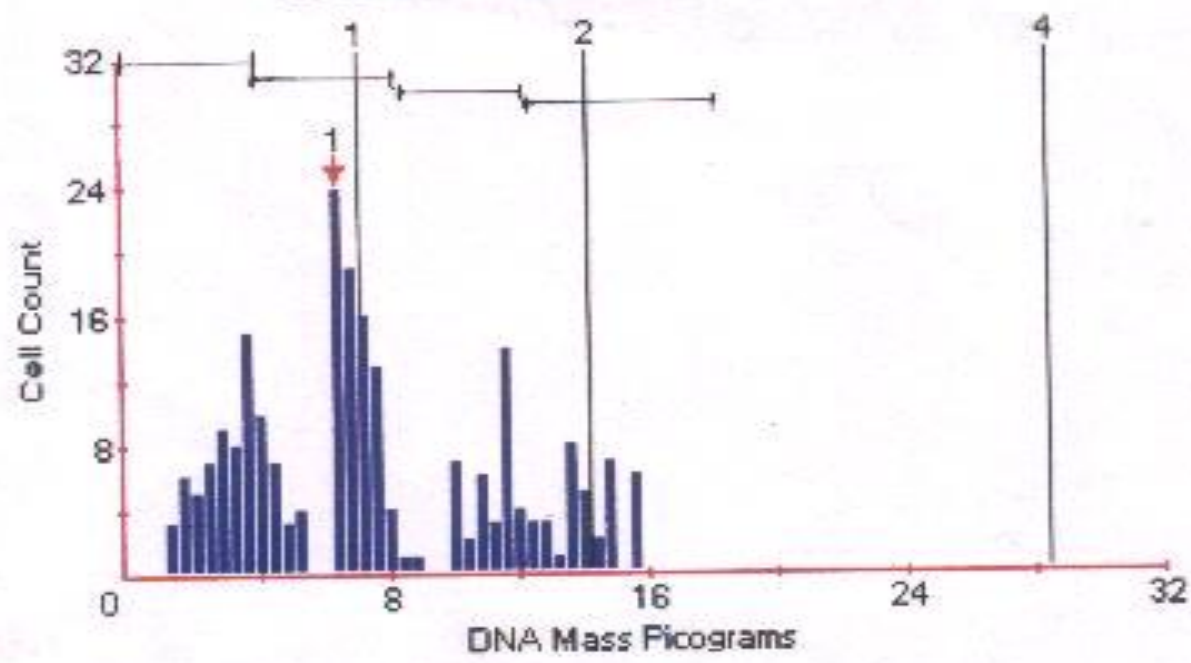

Cell Classes

Displayed : 123456

First Peak

Mass: 6.6 Pg.

DNA lndex 0.92

Area: $28.3 \mu^{2}$

Cells : 24

Second Peak

Mass: 0.0 Pg.

DNA index : 0.00

Area : $0.0 \mu^{2}$

Cells : 0

Field Count :18

Total Cell Count :226

Cells Displayed : 226

Cells Off Scale : 0 


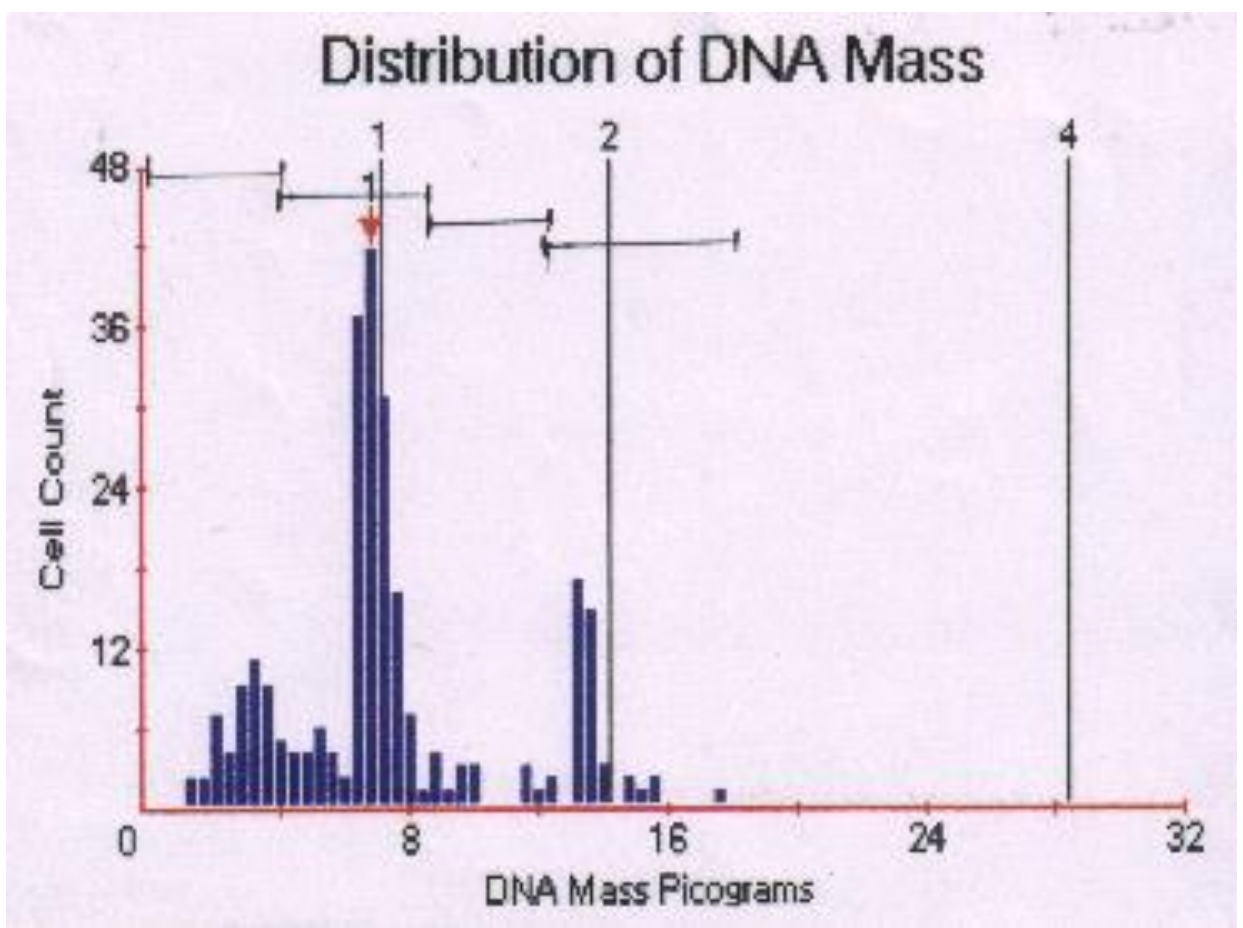

Cell Classes

Displayed : 123456

First Peak

Mass: 6.9 Pg.

DNA lndex 0.97

Area: $36.4 \mu^{2}$

Cells : 42

Second Peak

Mass: $0.0 \mathrm{Pg}$.

DNA index : 0.00

Area : $0.0 \mu^{2}$

Cells : 0

Field Count :44

Total Cell Count :261

Cells Displayed : 261

Cells Off Scale : 0

Histogram (4): DNA histogram of group III showing diploid peak.

Table (3): Effect of E.S seed oil on sperm count.

\begin{tabular}{|c|c|c|c|}
\hline $\begin{array}{c}\text { Sperm count } \\
(\text { No.x10 }\end{array}$ & Group I & Group II & Group III \\
\hline Mean & 13.7125 & 41.85 & 2.525 \\
\hline \pm SD & 1.438 & 4.614 & 0.599 \\
\hline P value & & $\mathrm{P}<0.05$ & $\mathrm{P}<0.01$ \\
\hline Significance & & $\mathrm{S}$ & $\mathrm{S}$ \\
\hline
\end{tabular}

Histogram (5): Effect of E.S seed oil on sperm count.

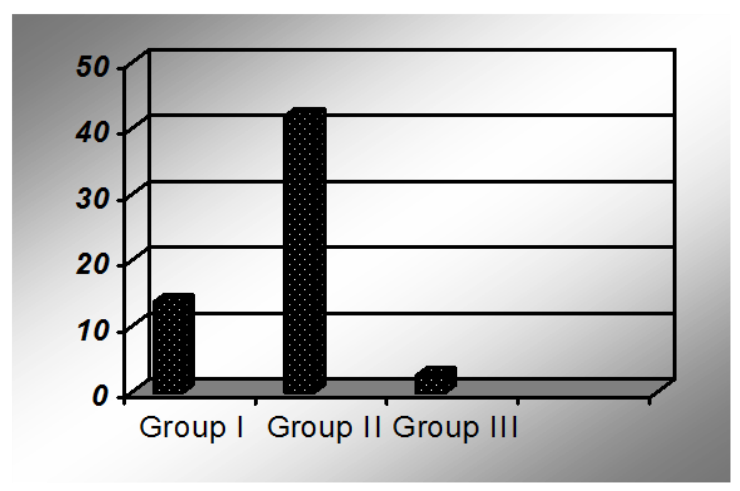


Table (4): Effect of E.S. seed oil on serum testosterone levels (ng\ml).

\begin{tabular}{|c|c|c|c|}
\hline & Group I & Group II & Group III \\
\hline Mean & 0.845 & 1.5 & 0.1125 \\
\hline \pm SD & 0.307 & 0.248 & 0.063 \\
\hline
\end{tabular}

Histogram (6): Effect of E.S. seed oil on serum testosterone levels (ng $\backslash \mathrm{ml})$.

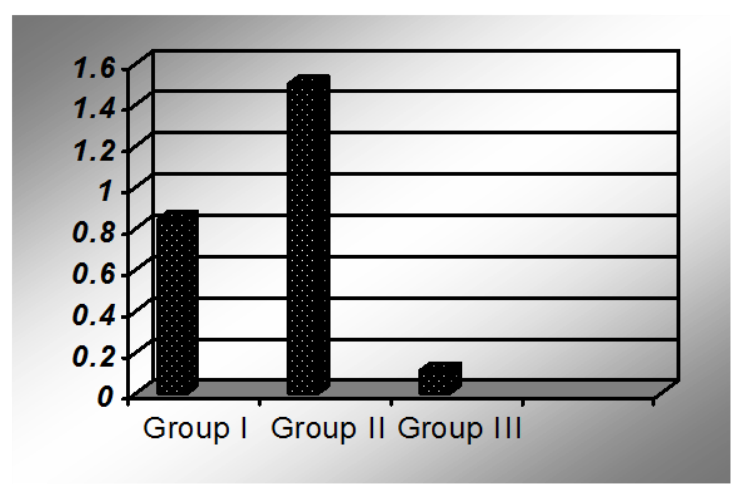

Table (5): Effect of E.S. seed oil on testis and epididymis weight.

\begin{tabular}{|c|c|c|c|}
\hline & Group I & Group II & Group III \\
\hline Mean testis & 1.0797 & 1.2987 & 1.1531 \\
Weight/gm \pm SD & \pm 0.142 & \pm 0.047 & \pm 0.082 \\
& & & 0.1413 \\
Mean epididymis & 0.1160 & 0.163 & \pm 0.027 \\
weight/gm \pm SD & \pm 0.026 & \pm 0.37 & \\
\hline
\end{tabular}

Histogram (7): Effect of E.S. seed oil on testis and epididymis weight.

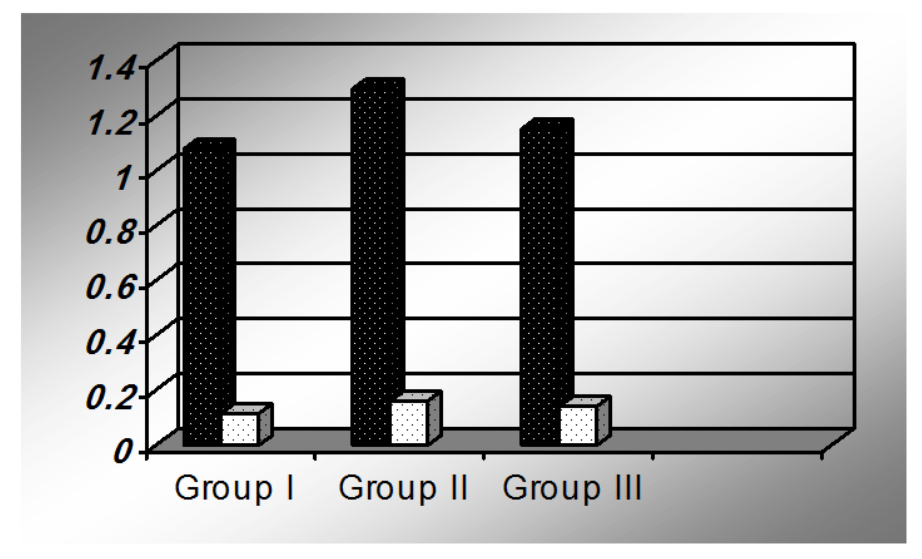




\section{Discussion}

Eruca Sativa seed oil is widely used by many males to improve their sexual performance. This study was undertaken to throw a red light on the haphazardly used medical plants. E.S. seed oil was used to evaluate its effect on male fertility by studying the testicular structure, diameter of seminiferous tubules, DNA content; sperm count .testosterone hormone level, testis and epididymis weight.

The valuable effects of the oil or its hazards are usually related to its fatty acid contents. It contains erucic acid, oleic acid and linolenic acid. The esse ntial fatty acids linolenic acid and oleic acid preserve the mitochondrial integ rity and the rate of formation of acetyl CoA necessary to the activity and motility of spermatozoa (McLennan \& Dallimare, 1995). Also, the study of Holman et al., (1982) proved that linolenic acid is essential and has a role in the structure and function of cell membrane. Blesbois et al., (1997) sug gested that dietary fatty acids represent an important factor in male fertility because of their incorporation in both the seminal fluid and spermatozoa.

Image analysis is a method of quantifying the microscopic image of a cell by computer analysis of its DNA content. It is the most recent available application in determining DNA content and cell cycle analysis (Kim et al., 1997). DNA image analysis is an accurate assessment of spermatogenesis (Takahiro et al, 1997).

The observed increase in the seminiferous tubule diameter produced by the low dose of E.S seed oil may be due to the proliferation and the increased activity of spermatogenic cells. In contrast, the observed reduction of the seminiferous tubule diameter following the administration of high dose of E.S. seed oil may be due to the disturbance of the rate of division of spermatogenic cells leading to the reduction of spermatogenic activity. The studies of Ravet et al., (1985), supported this observation; they proved that animals fed a diet containing high erucic acid showed inhibition of spermatogenic cell division with degeneration of some cells and tubular shrinkage.

In the present study, the control DNA histogram showed a peak of diploid cells, DNA histogram of group II showed a peak of haploid cells while group III showed peaks of diploid cells and s-phase cells. The difference is based on the DNA content of the cells. The low dose of E.S. seeds oil produced a high rate of proliferation of the haploid cells resulting in stimulation of spermatogenesis and increase sperm count. While the large dose inhibited DNA synthesis and produced a decrease in cell division resulting in hypo spermatogenesis diagnosed by the diploid peak showed in the DNA histogram and also proved by the decreased sperm count.

The spermatogenic activity is under the control of testosterone hormone secreted by Leydig cells (Stevens \& lewe, 1996) and the leuteinizing hormone secreted by the LH cells of anterior pituitary (Payne \& youngblood, 1995). The high dose of E.S. seed oil adversely affected the Leydig cell structure and caused a decrease in testosterone hormone level. This may be due to the high erucic acid content of E.S. seeds oil which affects the integrity of Leydig cell membrane resulting in a decrease in testosterone hormone level (Blesbois et al., 1997). So the rate of spermatogenesis is affected by the high erucic acid content either directly through its action on the membrane of spermatogenic cells or 
indirectly through its action on Sertoli cells or Leydig cells (Sebokova et al., 1990).

Menon et al., (1981) reported that the essential fatty acids were essential factors for the reproductive activity. So essential fatty acid contents of E.S seed oil may result in the high vital activity of the spermatogenic cells and sertoti cells leading to the observed increase of the seminiferous tubules diameter and the high production of spermatogonia. The activity effect of low dose may be due to elevation of $\mathrm{LH}$ receptor concentration on Leydig cells (Payne and Youngblood, 1995) with subsequent activation of testicular responsiveness to gonadotrophins and activation of 17 hydroxylase in Leydig cells.

The present study revealed that, the weight of testis did not change significantly by administration of E.S seed oil. These results are in agreement with those of other workers conducting long-term and multiple-generation studies with rats fed on hydrogenated fats (Duthie and Barlow, 1982; Zevenbergen et al., 1988).

The present study showed a significant increase in the epididymis weight in-group II. But this increase was not significant in-group III. These results may be related to the increased sperm count caused by low dose (Payne \& Youngblood, 1995).

It is concluded that the low doses of $E$ S seed oil produced activation of spermatogenesis whereas the high dose of E.S. seed oil produced marked inhibition of the spermatogenic activity probably due to the high content of erucic acid. So many studies are required to accurately adjust the dose of this widely used oil.

\section{References}

1. Bacus, S. (1988): An optical microscopical image analysis system with clinical applications. In clin product rev.: 26. $965-983$

2. Blesbois, E., Lessire, M., and Hernier, D. (1997): Effect of dietary fat on fatty acid composition and fertilizing ability of semen. Biology of reproduction. 56: 1216-1220.

3. Boulos , L. (1983): Medical Plants of North Africa. Text book, single ed. Weiss L, El sevir New York, P71

4. Drury, R.A. and Wallington, E.A. (1980):Carleton's histological technique 5th ed .London, New York, Oxford University press.P 138

5. Duthie, I.F. and Barlaw , S.M. (1982): A rat life span study comparing partially hydrogenated fish oil, partially hydrogenated soy bean oil and rap-seed oil included in the diet at high levels: J.A chem .. Soc. 48:851 - 859.

6. EL-Gendy, A.M. (2000): Effect of Eruca Sativa oil on some heamatological and biochemical parameter in male albino rats. A preliminary study .J. Egypt. Ger. Zool. 32 (A), comparative physiology 255266.

7. Flander, A.and Abdel - Karim, S.M. (1985) : A stdy of certain drugs used in folk medicine $\mathrm{J}$ Am. Oil Chem . Soc 62 (7) : 1137 - 1145 cited in Thabet, C( 1990) Ph D.

8. Gehauser, C., Liu,J., Moriarty , R.M. and Pezzute,J.M.(1997): Cancer chemopreventive potential of sulforamate, a novel analogue of sulforaphane that induce phase 2 drug metabolizing enzymes. Cancer Res, 57(2):272-278.

9. Grieve, M. (1959): Modern 
herbs, vol. II, Hafner Publishing co., New York P.681.

10. Holman,R.T., Johnson, S.and Hatch, T. (1982) : A case of human linolenic acid deficiency involving neurological abnormalities J.Clin. Nutr. $35: 617$ - 623.

11. Kim Ed, Lin, W.W. , Abrams , J.K. and Ipshuetg, L.I (1997): Image analysis assessment of the animal testis biopsy in male infertility, J. urology 158, $82-84$ July.

12. Mclennan P.I., and Dallinore , J . A.( 1995) Dietary canola oil modifies myocardial fatty acids and inhibist cardiac arrgythmias in rats in rats J. Nutr. 125(4).1005-9

13. Menon, N. K., Moore, C. And Dhopesh Worker, G. A. (1981): Effect of essential fatty acid deficiency on fetal rat tissue .J. Nutrition II: 1602-1610.

14. Payne, A. And Youngblood, G.L. (1995): Regulation of expre ssion of enzymes in Leydig cells. Biology Repronds 52: 217-225

15. Ravet, D., Chambaz, J. and Beraziat, G. (1985): Essential fatty acid interconversion during gestation in the rat. Biochemica et Biophysica Acta .833:161 -164.
16. Sebokova, E.; Gargl, L. , and Clandinim , M.T . (1990): Alteration in lipid composition of rat testicular plasma membrane by dietary fatty acids changes responsiveness of Leydig cells and testosterone synthesis. J. Nutrition 120:610-618.

17. Steven, A. and Lowe, j. (1996):Male Reproductiv System In Human Histology 2nd Ed. Mosby. London and Barcelona.P323

18. Takahiro, I., Masato, F., Hirokagu, T. \& Sadao, K. (1997): Image cytometry for quantitative analysis of DNA in the testes of infertile men with varicocele: comparison with flow cytometry $\mathrm{J}$. urology 157. 147.

19. Thabit, C. (1990): A study of certain drugs used in folk medicine with probable diuretic action. Ph.D. thesis pharmaceut. Sci. faculty of pharmacy Cairo University.

20. Williams, F. (1985):Reasoning with statistics. How to read quantitative research. 3rd Ed. Halt, Rinehart and Winston, New York.

21. Zevenbergen, J.L., Houstmuller, U.M. and Gottenbos J.J. (1988): Linoleic acid requirement of rats feed trans fatty acids. Lipids23,17818. 


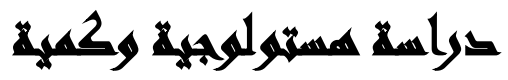

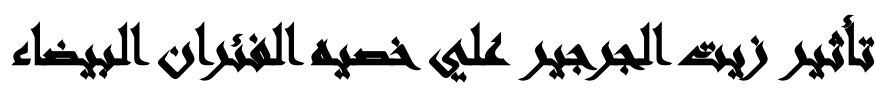

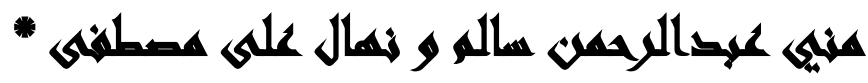

قسم الهستولوجى .كلية الطب وقسم علم الحيوان كلية العلوم *جامعة الأزهر

يستعمل زيت الجرجير على نطاق واسع فن الطب الشعبى .وتمدف هذه الدراسة الى دراسة التأثير الختمل

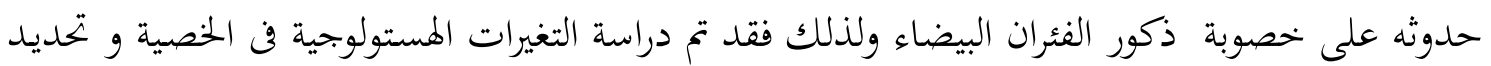

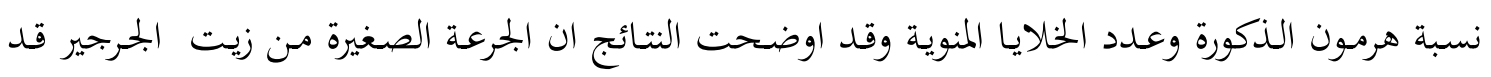

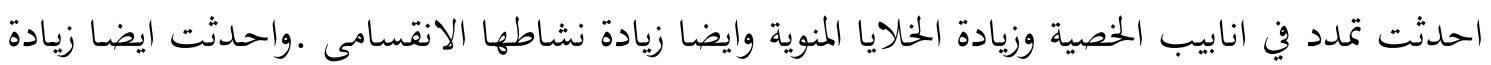

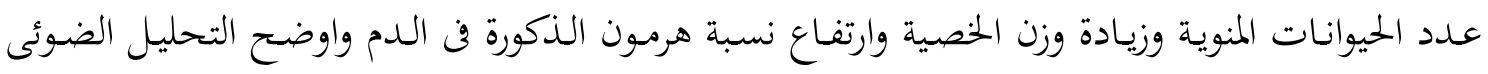

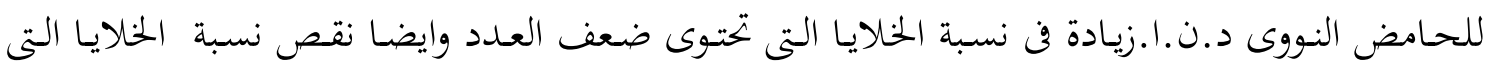

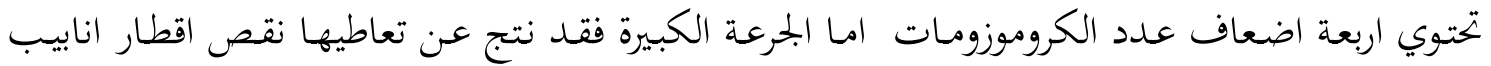

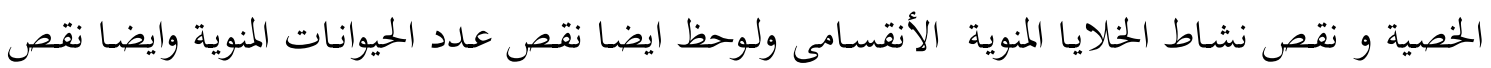

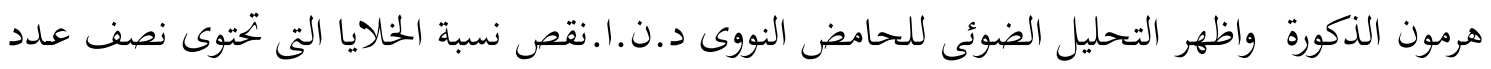

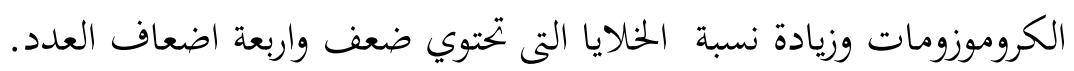

